\section{International Registration of Cultivar Names for Unassigned Woody Genera: December 2016 to January 2021}

\author{
Stefan B. Lura and Alan T. Whittemore \\ U.S. National Arboretum, 3501 New York Avenue Northeast, Washington, \\ DC 20002
}

Additional index words. cultivar, shrub, tree

Between Dec. 2016 and Jan. 2021, 14 cultivar epithets were newly registered with the International Cultivar Registration Authority (ICRA) for Unassigned Woody Genera. Additionally, 14 earlier but apparently unpublished registrations accepted by the former ICRA for Viburnum and Unassigned Woody Genera were discovered. Those registrations have been completed here through formal publication. Most of these names do not yet have standard specimens. We are working to obtain good herbarium specimens for many of these cultivars, and standards will be designated when we have suitable material.

Authority for cultivar name registrations in the genus Tilia was transferred in 2018 from this ICRA to Mr Eike Jablonski, LTA, Dept. Horticole et Arboretum, 72, Avenue Lucien Salentiny, L-9080 Ettelbruck, GrandDuché Luxembourg.

Prospective registrants are encouraged to contact the registrar to request a registration form. For contact details and for a list of genera that have been approved for registration with this ICRA, please see the main contact page for the American Public Gardens Association at https://www.ishs.org/sci/icralist/3. $\mathrm{htm}$. A full listing of genera covered by international registration authorities may be accessed at https:/www.ishs.org/sci/taxlist/taxlist.htm, and a page is being created for registrations conducted for this ICRA by the U.S. National Arboretum at https://www.usna.usda.gov/science/icra/. Please note that the cultivars' descriptions, and any expressed or implied sentiments about the cultivars below, are strictly based on information provided by their respective registrants; they do not constitute any form of valuation or endorsement by the United States Department of Agriculture.

Aesculus glabra 'Herkenrode'. Registered 28 Jan. 2019. Registrant: Joke Osselaer, Arboretum Wespelaar, Grote Baan 63, 3150 Haacht (Wespelaar), Belgium. Philippe de Spoelberch (of Arboretum Wespelaar) purchased the original plant as a seedling in 1994 from Arboretum

Received for publication 9 Apr. 2021. Accepted for publication 15 May 2021.

Published online 9 July 2021.

A.T.W. is the corresponding author. E-mail: Alan.Whittemore@usda.gov.

This is an open access article distributed under the CC BY-NC-ND license (https://creativecommons. org/licenses/by-nc-nd/4.0/).
Waasland, also in Belgium. The seedling was raised in 1991. At the time of acquisition, it was labeled Aesculus glabra var. erable to A. glabra var. arguta. The newly registered cultivar appears to be a selection of A. glabra var. glabra.

Arboretum Wespelaar selected this seedling (Wespelaar accession number 91329) in 2005 because of its round form, which it maintains without pruning, and autumn foliage color. It displays warm orange-red autumn foliage starting in the first half of September and lasting until the end of September every year. The leaves display fall color for $\approx 1$ month before falling. The new cultivar is named after the garden of Herkenrode, where Philippe de Spoelberch started his botanical collection.

Aesculus glabra 'Herkenrode' grows as a rather small, rounded, low-branching, wellbranched tree. The original seedling, which has never been pruned, achieved a height and spread of $7 \mathrm{~m}$, with a basal circumference of $110 \mathrm{~cm}$ at 27 years of age. Its leaves (including the petioles) are 16 to $28 \mathrm{~cm}$ long and 15 to $20 \mathrm{~cm}$ wide, with petioles 7.5 to $15 \mathrm{~cm}$ in length; the petioles are hairy. The five to six wide, widest in the middle, with 12 to 20 or more pairs of veins. The leaflet undersides are hairy on the veins and sparsely hairy between veins. Petiolules are short (1.2-2 $\mathrm{mm})$. Leaves turn a mixture of autumn colors, including red group RHS 45C (Cherry Red) and RHS 46A/47A/47B (Currant Red), orange red group RHS 42B/42C $+34 \mathrm{~B}$, and yellow orange group RHS 23B (Cadmium Orange). Its flowers appear from the end of April to mid-May. They are yellow green (RHS 154C) over yellow (RHS 3D; Chartreuse Yellow) to yellow-white (RHS 158C) and are borne in erect, cylindrical, sparsely produced panicles. The flowers have four petals, with stamens exceeding the petals in length. Fruits are up to $3 \mathrm{~cm}$ in diameter, broadly obovoid, and unevenly covered in prickles. At maturity, they often display a pinkish blush (RHS 35-C, Brick Red) over a green-yellow base (RHS 160-A, 151-A). The bark of the trunk is rough and fissured at maturity.

This cultivar performs well during both rainy summers and dry, warm summers. It has proven to be adaptable in Belgium in sargentii, but that name is probably prefleaflets are 7 to $13 \mathrm{~cm}$ long and 2.5 to $4 \mathrm{~cm}$
U.S. Department of Agriculture (USDA) Hardiness Zones 7 and 8. It shows its autumn foliage color consistently each year and has a naturally round shape that provides interest during all seasons. Its limited dimensions should make it a useful plant for smaller gardens. The original specimen at Arboretum Wespelaar has never been pruned; however, it still maintains its rather small size.

An herbarium specimen for this cultivar has been deposited at Arboretum Wespelaar under identifier J. Ossaer 2961; here, it is designated as the nomenclatural standard. Digital photographs have been submitted to the registrar.

Chaenomeles × superba 'Glowing Ember'. Registered 19 Apr. 1957. Registration was performed by the American Association of Nurserymen (AAN) (AAN registration number 525); however, no publication of registration action has been located by the present registrars. Registrant: J. J. Pinney, Willis Nursery Co., Ottawa, KS. This cultivar was developed by A. E. Willis, Willis Nursery Co., in 1945. It was introduced in 1954 as Chaenomeles lagenaria 'Willis Strain' but was changed in 1955 to 'Glowing Ember'. It was previously published as 'Glowing-Ember' (Arnoldia 1963;23:17-75, Cultivars in the Genus Chaenomeles) where its previous AAN registration as 'Glowing Ember' was not indicated. It was selected for its upright growth, very bushy and uniform habit, and floriferous nature, as well as for its scarlet flowers. It is described in Arnoldia as having bright orange-red, single flowers and apple-shaped, umbilicate fruits. Materials sufficient for the designation of a nomenclatural standard for this cultivar are currently lacking.

Daphne odora 'Ringmaster'. Registered 14 Aug. 2019. Registrant: Philip M. Normandy, Brookside Gardens, Wheaton, MD. This cultivar exhibits pure white flowers opening from white buds and clear, yellow-white marginal foliar variegation. Its growth habit is upright, taller than wide, and it produces occasional branches with all-white leaves. A full description of Daphne odora 'Ringmaster' and its background was first published in Arnoldia [1985;45(2):15-16. Cultivars of Japanese Plants at Brookside Gardens-II by Carl R. Hahn and Barry R. Yinger]. It was obtained from the garden of Yoshimichi Hirose of Suginami-ku, Tokyo, Japan, without a cultivar epithet in Mar. 1982 by Barry R. Yinger (Yinger collection number 1894) for Brookside Gardens. It was described without a cultivar name on page 51 of the 1911 catalog of Yokohama Nursery Company, Yokohama, Japan. It was named by Carl R. Hahn of Brookside Gardens. Documentation for this cultivar was originally submitted for registration on 5 Mar. 1988, but the registrar at the time declined to register the name because of a lack of photographs and an herbarium specimen as part of the submission (because this was not a formal requirement for cultivar name registration, it should not have prevented registration).

An herbarium specimen at the U.S. National Arboretum Herbarium with barcode NA0025396 (bearing collector identifier $F$. $G$. Meyer 21757) was designated as the 
nomenclatural standard for this cultivar on 2 July 2007 by Donald H. Voss of Vienna, VA (for more information, see Hanburyana 2009;4:40-57).

Distylium racemosum 'Guppy'. Registered 14 Aug. 2019. Registrant: Philip M. Normandy, Brookside Gardens, Wheaton, MD. This cultivar exhibits a dense, dwarf, rounded growth habit with small, 3- to 5-cmlong and 1- to 2-cm-wide leaves. A full description of Distylium racemosum 'Guppy' and its background were first published in Arnoldia [1985;45(2):15. Cultivars of Japanese Plants at Brookside Gardens-II by Carl R. Hahn and Barry R. Yinger]. It was obtained from Garden Wako, Takarazuka, Osaka Prefecture, Japan, without a cultivar epithet in Winter 1977 by Barry R. Yinger (Yinger collection number 274) for Brookside Gardens. It was named by Barry R. Yinger. Documentation for this cultivar was originally submitted for registration on 5 Mar. 1988, but the registrar at the time declined to register the name because of a lack of photographs and an herbarium specimen as part of the submission (because this was not a formal requirement for cultivar name registration, it should not have prevented registration). At present, there is insufficient material available to the ICRA for the designation of a nomenclatural standard for this cultivar.

Fraxinus bungeana 'Sunflash'. Registered 26 July 2018. Registrant: Anthony Aiello, Morris Arboretum of the University of Pennsylvania (9414 Meadowbrook Avenue, Philadelphia, PA 19118). The original plant of Fraxinus bungeana 'Sunflash' (Morris Arboretum number $2010-213^{*} \mathrm{~A}$ ) is a chance seedling grown from seed wild-collected in China under field collection number NACPEC10-042, Fraxinus bungeana, during an expedition of the North America China Plant Exploration Consortium. This collection was made on 29 Sept. 2010, at Bai Hua Shan, Beijing Municipality. In Sept. 2014, the registrant first noticed a variegated plant among a group of seedlings from this collection (Morris Arboretum accession number 2010-213), and this individual was given a separate accession number.

This variety, which had not yet flowered at the time it was named and registered, is the first recorded cultivar of Fraxinus bungeana. It has a growth rate and habit similar to the species (the original plant reached a height of $2.54 \mathrm{~m}$ and width of $0.64 \mathrm{~m}$ after 8 years), but it differs in its leaves that are patterned with a mixture of green, yellow, and cream. The leaflet margins are colored irregularly in yellow to cream, with bands of each color varying in width and the centers of most leaflets remaining green. This variegation has been consistent since it was first observed and persists throughout the season. The variety was propagated several times since 2017 . Its name is a reference to the color of its foliage. An account of this new cultivar along with a photograph have been published in Arnoldia [2017;75(2):32-33]. A nomenclatural standard specimen will be prepared and deposited at the Herbarium of the U.S.
National Arboretum when enough material is available. Digital images have been submitted to the registrar.

Jasminum sambac 'Xiangfei 5'. Registered 5 June 2020. Registrants: Li Chunniu, $\mathrm{Li}$ Xianmin, and $\mathrm{Bu}$ Zhaoyang, Nanning, Guangxi Province, People's Republic of China. The original plant was raised by $\mathrm{Li}$ Chunniu at Hengxian, Nanning, Guangxi Province in 2015, and it was selected in 2019. It was raised from open-pollinated seed of a double-flowered diploid form that is commonly grown in China. Unlike its parent, 'Xiangfei 5 ' bears single flowers and is tetraploid, which was determined by flow cytometry. "Xiangfei" means "beautiful and fragrant."

Jasminum sambac 'Xiangfei 5' forms a small shrub or liana with dark green, leathery, ovate to lanceolate leaves. Its salverform corolla is 3.0 to $3.5 \mathrm{~cm}$ in diameter, white, and fragrant, with nearly round petal lobes. The stigma is longer than the corolla tube.

A comparable form that is grown in China also bears single, white, fragrant flowers, but it is triploid. Its stigma is shorter than the corolla tube. Digital images have been submitted to the registrar and a nomenclatural standard specimen will be prepared and deposited at the Herbarium of the U.S. National Arboretum.

Parrotia persica 'Red October'. Registered 1 Dec. 2016. Registrant: Joke Osselaer, Arboretum Wespelaar [Grote Baan 63, 3150 Haacht (Wespelaar), Belgium]. Philippe de Spoelberch (of Arboretum Wespelaar) received the original plant as one of 10 seedlings in 1998 from nurseryman Dominique Duhaut, who had raised them in 1997 from seed collected in Azerbaijan. The 10 seedlings were planted in various positions at Wespelaar and Herkenrode. They were quite variable in autumn colors. All plants exhibited broad growth and lacked any leader.

Philippe de Spoelberch selected this seedling (Wespelaar accession number 98023) for its superb Bordeaux wine-red autumn color, which he regarded as one of the best colorings of all Parrotia accessions in Arboretum Wespelaar, including Herkenrode. In 2011, he sent material to Paul Reimer (Reimer's Nurseries Ltd., Yarrow, BC, Canada) to propagate it. Together, de Spoelberch and Reimer initially chose the name 'Red Bull' for the new variety because of its "energizing" red coloration and vigorous growth. However, because of trademark protections, the use of this name as a cultivar epithet is prohibited, and Philippe de Spoelberch selected a new epithet 'Red October' because of its red coloration in October. This name also recalls the name of a fictional Soviet submarine in a well-known movie (The Hunt for Red October). Because the variety was circulated before the selection of the new name, it may still be found referenced or sold under the invalid synonym 'Red Bull'.

Parrotia persica 'Red October' grows as a large, intricately branched, spreading shrub; it reached a height of $3.5 \mathrm{~m}$ and a spread of 7 $\mathrm{m}$, with a circumference of $77 \mathrm{~cm}$ at a height of $0.6 \mathrm{~m}$ at 20 years of age. Its spring foliage is bronze-green, maturing to lettuce green (RHS 144A) during summer. The leaves are ovate to (more usually) obovate, 7 to $13 \mathrm{~cm}$ wide, and 4.5 to $7.5 \mathrm{~cm}$ broad, with short petioles (up to $6 \mathrm{~mm}$ ). The leaf margins are shallowly and unevenly toothed or merely wavy toward the apex. Its foliage changes color consistently each autumn, and it does so from a young age. The coloring begins at the top of the crown and progresses to the inner branches of the tree, with colors fading from deep purple to red-orange and finally to orange-brown inside the shrub. The outer leaves fall earlier.

This cultivar has been observed to exhibit red fall color even in the wet coastal climate of western Canada, unlike most other selections of the species. It can be trained into a small tree by working it at a young age, before the wood hardens. It has been found completely hardy in Belgium in USDA Hardiness Zones 7 and 8.

An herbarium specimen for this cultivar has been deposited at Arboretum Wespelaar under identifier J. Ossaer 2495 and is designated here as the nomenclatural standard. Digital photographs have been submitted to the registrar.

Philadelphus 'Bolero'. Registered 15 Feb. 2017. Registrant: Sergey Loktev, microrayon Barybino, district Domodedovo, Moscow oblast, Russia. This cultivar originated as a chance open-pollinated seedling of unknown parentage that was first observed in the registrant's garden in 2013, at which time it was estimated to be 3 years old. It was selected for its unique characteristics in 2014. It has grown to a height of $1.5 \mathrm{~m}$ and a spread of $1.4 \mathrm{~m}$ after 6 years, with a maximum recorded shoot diameter of $2 \mathrm{~cm}$. Its abundantly produced young shoots are green and glabrous. Leaves are green, lighter on the reverse side, and oval in shape, with a rounded base and pointed tip, serrate edges, and with pubescence beneath; petiole length is $1 \mathrm{~cm}$. Inflorescence length is $5 \mathrm{~cm}$, bearing five to seven flowers per inflorescence. Flower form is semi-double, $3 \mathrm{~cm}$ in diameter, with oval petals having irregularly serrate edges; petals are white and the stamen number is $\approx 15$. There is no floral scent. The flowering season is very early to midseason, with the duration from first flower opening to the fading of the last flower up to $30 \mathrm{~d}$. Digital images have been submitted to the registrar. A nomenclatural standard specimen will be prepared and deposited at the Herbarium of the U.S. National Arboretum.

Philadelphus 'Festival'. Registered 15 Feb. 2017. Registrant: Sergey Loktev, microrayon Barybino, district Domodedovo, Moscow oblast, Russia. This cultivar originated as a chance open-pollinated seedling of unknown parentage that was first observed in the registrant's garden in 2012, at which time it was estimated to be 2 years old. It was selected for its unique characteristics in 2013. It has grown to a height of $1.9 \mathrm{~m}$ and a spread of $1.6 \mathrm{~m}$ after 6 years, with a maximum recorded shoot diameter of $2 \mathrm{~cm}$. Its young shoots are green, partially tinted red, and 
produced in average numbers. Leaves are dark green, lighter on the reverse side, and lanceolate to ovate in shape, with a rounded base and pointed tip, serrate edges, and slightly pubescent beneath; petiole length is $0.5 \mathrm{~cm}$. The inflorescence length is $15 \mathrm{~cm}$, bearing seven to nine flowers per inflorescence. Flower form is semi-double, $4 \mathrm{~cm}$ in diameter, with oval outer petals and narrow, curled inner petals; petals are white and the stamen number is $\approx 15$. There is no floral scent. The flowering season is early to midseason, with the duration from first flower opening to the fading of the last flower up to $25 \mathrm{~d}$. Digital images have been submitted to the registrar. A nomenclatural standard specimen will be prepared and deposited at the Herbarium of the U.S. National Arboretum.

Philadelphus 'Igrushka'. Registered 15 Feb. 2017. Registrant: Sergey Loktev, microrayon Barybino, district Domodedovo, Moscow oblast, Russia. This cultivar originated as a chance open-pollinated seedling of unknown parentage that was first observed in the registrant's garden in 2013, at which time it was estimated to be 3 years old. It was selected for its unique characteristics in 2014. It has grown to a height of $2.3 \mathrm{~m}$ and a spread of $1.3 \mathrm{~m}$ after 6 years, with a maximum recorded shoot diameter of $2.5 \mathrm{~cm}$. The bush is characteristically compact in shape. Its young shoots are green, partially tinted red, and produced in average numbers. Leaves are dark green, reddish when young, and lanceolate in shape; they have an ovate base and pointed tip, are scarcely serrate, and are without pubescence. The petiole length is $0.7 \mathrm{~cm}$. Inflorescence length is $9 \mathrm{~cm}$, bearing five to seven flowers per inflorescence. Flower form is open, single-petaled, and $3 \mathrm{~cm}$ in diameter, with round petals having serrate edges; stamen number is $\approx 20$, and there is no floral scent. The flowering season is early to midseason, with a duration from first flower opening to the fading of the last flower of up to $20 \mathrm{~d}$. Digital images have been submitted to the registrar. A nomenclatural standard specimen will be prepared and deposited at the Herbarium of the U.S. National Arboretum.

Philadelphus 'Laplandiya'. Registered 15 Feb. 2017. Registrant: Sergey Loktev, microrayon Barybino, district Domodedovo, Moscow oblast, Russia. This cultivar originated as a chance open-pollinated seedling of unknown parentage that was first observed in the registrant's garden in 2013, at which time it was estimated to be 3 years old. It was selected for its unique characteristics in 2014. It has grown to a height of $1.3 \mathrm{~m}$ and a spread of $1.3 \mathrm{~m}$ after 6 years, with a maximum recorded shoot diameter of $1.5 \mathrm{~cm}$. Its young shoots are green and lack pubescence. Leaves are green, lighter in color beneath, and lanceolate in shape, with a rounded base, pointed tip, and serrate margins; they are without pubescence; petiole length is $0.5 \mathrm{~cm}$. Inflorescence length is up to $9 \mathrm{~cm}$, bearing five to seven flowers per inflorescence. Flower form is half-open, semi-double, and $4 \mathrm{~cm}$ in diameter, with ovate outer petals; petals are milky white and the stamen number is 15 to 20 . There is no floral scent. The flowering season is early to midseason, with a duration from first flower opening to the fading of the last flower of up to $20 \mathrm{~d}$. Digital images have been submitted to the registrar. A nomenclatural standard specimen will be prepared and deposited at the Herbarium of the U.S. National Arboretum.

Philadelphus 'Menestrel'. Registered 15 Feb. 2017. Registrant: Sergey Loktev, microrayon Barybino, district Domodedovo, Moscow oblast, Russia. This cultivar originated as a chance open-pollinated seedling of unknown parentage that was first observed in the registrant's garden in 2013, at which time it was estimated to be 3 years old. It was selected for its unique characteristics in 2014. It has grown to a height of $2 \mathrm{~m}$ and a spread of $2 \mathrm{~m}$ after 6 years, with a spreading shape and a maximum recorded shoot diameter of 2 $\mathrm{cm}$. Its young shoots are green and lack pubescence. Leaves are dark green, lighter in color beneath, and ovate in shape, with a rounded base, pointed tip, and serrate margins, and are without pubescence; petiole length is $1 \mathrm{~cm}$. Inflorescence length is $7 \mathrm{~cm}$, bearing five to seven flowers per inflorescence. Flower form is open, with extra outer petals, $3.5 \mathrm{~cm}$ in diameter; petals are rhombic in shape and milky white. The stamen number is 20 . There is a weak floral scent. The flowering season is very early to very lateseason, with a duration from first flower opening to the fading of the last flower of up to $40 \mathrm{~d}$. Digital images have been submitted to the registrar. A nomenclatural standard specimen will be prepared and deposited at the Herbarium of the U.S. National Arboretum.

Philadelphus $\times$ virginalis 'Frosty Morn'. Registered 11 Apr. 1955 (registration performed by the American Association of Nurserymen, AAN registration number 466, but no publication of registration action has been located by the present registrars). Registrant: Guy D. Bush, Bush's Nursery, Minneapolis, MN. This cultivar was selected by the registrant in 1946 from a cross between Philadelphus $\times$ virginalis 'Virginal' and $P . \times$ virginalis 'Minnesota Snowflake', and it was introduced to the trade in 1953. It was also patented (U.S. Plant Patent \#1174, filed 14 July 1951). The cultivar is a dwarf, compact, very finely branched plant with an ultimate height of $\approx 4 \mathrm{ft}$. It has small, dainty, lanceolate leaves. Branches weep because of the weight of the pure white, large, double, sweet-scented blooms in June and early July in Minnesota. Some blossoms also appear in late fall. The variety was noted by the registrant to be hardy in Minnesota's coldest winters. Material sufficient for the designation of a nomenclatural standard for this cultivar is currently lacking.

Prunus 'Chuhong'. Registered 4 Aug. 2020. Registrant: Nie Chaoren, Wuhan City, Hubei Province, People's Republic of China. The original plant was discovered growing wild on Gexian Mountain, Chibi City, Hubei
Province, in Mar. 2014, and it was propagated 3 years later. It is considered likely to be a hybrid of Prunus conradinae (perhaps with $P$. discoidea as the other parent) that arose spontaneously in a natural environment where the former species is common. It forms an umbrella-shaped deciduous tree 3 to $5 \mathrm{~m}$ high, with pink, concave, and wrinkled or wavy petals in obvious corymbs and slender, wide-angled branches. It is named in part after the $\mathrm{Chu}$ State, a name for the region inhabited by the ancient Jingchu culture that was centered where modern Hubei Province lies during the "Spring and Autumn" Chinese historical period and for its pink flower color.

Prunus 'Chuhong' bears grayish brown bark with transverse fissures; its mature branchlets are reddish brown and the winter buds are ovoid. The leaf blades are obovate, oblong, or obovate-oblong, 9 to $13 \mathrm{~cm}$ long, and 4 to $7 \mathrm{~cm}$ wide; both surfaces are glabrous, abaxially pale green, and adaxially green. The leaf blade bases are rounded to broadly cuneate. The leaf margins are sharply, singly serrate, with each tooth having an acuminate to caudate apex and bearing a punctiform apical gland. The leaves have 13 to 16 secondary leaf veins on each side of the midvein. The petioles are 8 to $10 \mathrm{~mm}$ in length and glabrous, with one to two glands adaxially at the distal end. The stipules are linear, with glandular serrate margins; they are caducous after flowering. The inflorescences are corymbs with five to nine flowers and globular in shape. Peduncles are 1 to $2 \mathrm{~cm}$ long, and pedicels are 2 to $3.5 \mathrm{~cm}$ long and glabrous. Each calyx is tubular-campanulate, yellowish green, 3.5 to $4 \mathrm{~mm}$ long, 2.5 to 3 $\mathrm{mm}$ wide, and glabrous. Sepals are triangular-ovate, 2 to $3.2 \mathrm{~mm}$ long, and spreading, and the apex is obtuse to acute. Flowers open before leaves. The flower diameter is $\approx 1.5$ to $2 \mathrm{~cm}$. Flower buds are purple-red. The petals open abaxially pink, adaxially pale pink, and are ovate or obovate, apically two-lobed, and wrinkled or wavy. The flowering period is from early March to mid-March in Wuhan, starting several days before related 'Chujin' (see the following registration entry).

In contrast, the putative parent species, Prunus conradinae, has a broadly ovoid crown with stocky, upright branches that emerge at narrow angles, with white flowers that open 3 to $5 \mathrm{~d}$ later than those of 'Chuhong' and have flat petals that are wedge-shaped at the base. These occur in tight inflorescences with extremely short peduncles.

An herbarium specimen for this cultivar has been deposited at Herbarium of Wuhan Botanical Garden, Chinese Academy of Sciences under identifier HIB0186391. Here, it is designated as the nomenclatural standard. Digital photographs have been submitted to the registrar.

Prunus 'Chujin'. Registered 1 Jan. 2021. Registrant: Nie Chaoren, Wuhan City, Hubei Province, People's Republic of China. The original plant was discovered growing wild on Gexian Mountain, Chibi City, Hubei Province, in Mar. 2014. It was propagated 3 years later. It is considered likely to be a hybrid of 
Prunus conradinae that arose spontaneously in a natural environment where the former species is common. It forms a deciduous tree 3 to $5 \mathrm{~m}$ high, with pink, rounded to obovate petals in corymbs or racemose corymbs produced in dense masses along the branches (reminiscent of the floret density seen in many mophead Hydrangea inflorescences). It is named in part after the Chu State, a name for the region inhabited by the ancient Jingchu culture that was centered where modern Hubei Province lies during the "Spring and Autumn" Chinese historical period. "Jin" is a transliteration of a Chinese character that is used to describe bright and beautiful colors and is in reference to the densely produced clusters of pink flowers.

Prunus 'Chujin' bears reddish brown bark with transverse fissures. Its mature branchlets are reddish brown and the winter buds are ovoid. The leaf blades are obovate or obovate-oblong, 7.5 to $11 \mathrm{~cm}$ long, and 4.2 to 6.8 $\mathrm{cm}$ wide; both surfaces are glabrous, abaxially pale green, and adaxially deep green. The leaf blade bases are broadly cuneate to rounded, and apices are acuminate. The leaf margins are sharply, singly serrate. The leaves' secondary leaf veins occur 13 to 16 on each side of the midvein. The petioles are 6 to 24 $\mathrm{mm}$ in length and glabrous, with one to two glands adaxially at the distal end. The stipules are linear, with glandular-serrate margins; they are caducous after flowering. The inflorescences are corymbs or racemose corymbs with five to nine flowers and globular in shape. Peduncles are 1 to $2 \mathrm{~cm}$ long, and pedicels are 1.8 to $3.5 \mathrm{~cm}$ long and glabrous. Each calyx is short-campanulate, reddish green or reddish brown, 4 to $5 \mathrm{~mm}$ long, 2 to $2.5 \mathrm{~mm}$ wide, and glabrous. Sepals are broadly triangular-ovate, 3 to $3.5 \mathrm{~mm}$ long, and reflexed; the apex is obtuse to acute. Flowers open before leaves and are $\approx 2$ to $3.2 \mathrm{~cm}$ across. Flower buds are purple-red. Petals open abaxially pink, adaxially pale pink, and are round or obovate; they are apically two-lobed. Petals are initially imbricate and separate later. The flowering period is from early March to mid-March in Wuhan, initiating several days after 'Chuhong' (see previous registration).

In contrast, the putative parent species, Prunus conradinae, has white flowers that occur several days later than those of 'Chujin', with narrow-triangular or lanceolate sepals. These occur in tight, umbellate inflorescences with extremely short peduncles.

An herbarium specimen for this cultivar has been deposited at Herbarium of Wuhan Botanical Garden, Chinese Academy of Sciences, under identifier HIB0186390. Here, it is designated as the nomenclatural standard. Digital photographs have been submitted to the registrar.

Prunus virginiana 'Halward's Choice'. Registered 18 Feb. 1996 (registration action previously unpublished). Registrant: Norma Campbell, Newmarket, Ontario, Canada. The original plant was collected from the wild in 1979. It displays a weeping form; however, its other characteristics are typical of Prunus virginiana. It is considered hardy in zones 2 to 9 of the Plant Hardiness Zones of Canada. This cultivar and its registration by the late Steven Clemants, Brooklyn Botanic Garden (registrar for the American Association of Botanic Gardens and Arboreta, ICRA for Cultivars of Unassigned Woody Genera) were recorded and registration text was drafted; however, registration was not completed by formal publication. Material sufficient for the designation of a nomenclatural standard for this cultivar is currently lacking.

Ribes ×gondouinii 'Gabreta'. Registered 22 May 2019. Registrant: Pascal Kissling (Záblatí, Czechia). This old cultivar is believed to have been selected and cultivated by the former German-speaking inhabitants of the Bohemian Forest Mountains of Czechia before 1946. It was first observed by the registrant in 2004, and it has been subsequently studied in detail to characterize it and ascertain its historical origins. It is locally known as "German currant" or "Old Šumava," and the new name 'Gabreta' is the Celtic name of the mountains in which it has been found growing in and around abandoned German villages. Although plants distributed across the area are thought to show clonal variation owing to long cultivation and both intentional and incidental natural spreading, with various numbered clones (now almost 100) undergoing study, a type clone of the cultivar originally found at Milešice, Czechia, has been chosen as numbered selection Riru 011.

The cultivar develops into an upright shrub with a height of $1.9 \mathrm{~m}$ and spread of $1.0 \mathrm{~m}$ at 10 years of age. Its stump sprouts may grow 0.7 to $1.0 \mathrm{~m}$ during their first season, but subsequent annual growth averages 10 to $30 \mathrm{~cm}$. 'Gabreta' displays characteristics of both ancestral parent species, Ribes petraeum and Ribes rubrum. From Ribes petraeum, it has notably inherited red coloration in its sepals, a flattened, pelviform flower and ciliate calyx, very acid fruit, late emergence from dormancy, strong fungal disease resistance, long vegetative buds, and a tall growth habit. From Ribes rubrum, it has most significantly inherited a lobed hypanthium, floral disc with a discrete nectariferous ring, and obtusilobate leaves. 'Gabreta' can be distinguished from the only well-known cultivar of Ribes $\times$ gondouinii, 'Gondouin Rouge', by a number of characteristics: its later emergence from dormancy, flowering, and fruiting; its upright rather than spreading growth habit; the lack of red coloration in its spring shoots; its obtuse-lobed rather than acute-lobed leaf; its flowers more flattened in profile compared with the more urceolate flowers of 'Gondouin Rouge'; and its larger, darker red berries and fruit possessing a pleasant aroma as compared with that of 'Gondouin Rouge', the fruit of which often have an unpleasant scent. From the related Ribes $\times$ pallidum 'Prince Albert' (in continental Europe, 'Prince Albert' is found under a variety of synonyms in assorted languages: 'Rouge de Hollande', 'Holländische Rote', 'Lübecker Johannisbeere', 'Rukem von Haarlem', 'Röda Holländska' vinbär, 'Holandský Červený', 'Olandụ raudonieji', 'Holandes Sarkanās', 'Punainen
Hollantilainen', 'Holandse Rode'), this cultivar can be distinguished by its upright rather than spreading growth habit, its obtuse-lobed rather than acute-lobed leaf, which also lacks stipitate glands under the main veins, the deeper red coloration in its flowers, which also have narrow petals and in front of sepals nectariferous ridges instead of calluses, and its darker colored and more acid fruit. Further botanical differences have been enumerated and the registrant will share them upon request. The fruit of 'Gabreta' make a very dark red jelly as compared with that made with other typical red currant varieties.

This name and a full description of this cultivar have been published by the registrant in the Czech journal Bio. The most inclusive presentation of information may be found elsewhere (Kissling P. \& Kissling J. Gabreta znovu vzkřrišená ze sutin zapomnění. Bio měsíčník, vh press Hradec Králové, 2015:8-9). This and the French, German, and English translations may be accessed at https://www.researchgate.net/ publication/337649586_Ribesia_3_kultivary_3_ miniatury (or https://tinyurl.com/Gabreta).

In addition to its cultivation at the registrant's Alenor conservation garden, this clone has been propagated and distributed to other institutions, and an herbarium specimen was prepared from it on 22 May 2019, and deposited at Musée Botanique Cantonal, Lausanne, which is designated here as the nomenclatural standard.

Spiraea thunbergii 'Fujino'. Registered 18 Feb. 1996 (registration action previously unpublished). Registrant: Harvey Sinnema, J. C. Bakker \& Sons Ltd., St. Catharines, Ontario, Canada. This cultivar originated in Japan and was first observed by the registrant in 1992. It was first propagated in 1993; then, it was introduced commercially in Canada by J. C. Bakker \& Sons, Ltd. in 1995. Spiraea thunbergii 'Fujino' forms a profusely blooming, upright bush, 3 to $5 \mathrm{ft}$ tall. Its flower buds appear very early and give the appearance of a red glow. The flowers open appleblossom pink and turn whitish pink. The foliage is light green in summer and turns yellowish orange in fall. The plant has demonstrated hardiness on both vegetative buds and flower buds in USDA Hardiness Zone 4. This cultivar and its registration by the late Steven Clemants, Brooklyn Botanic Garden (registrar for the American Association of Botanic Gardens and Arboreta, ICRA for Cultivars of Unassigned Woody Genera) were recorded and registration text was drafted; however, registration was not completed by formal publication. Material sufficient for the designation of a nomenclatural standard for this cultivar is currently lacking.

Viburnum $\times$ burkwoodii 'Carlotta'. Registered 26 June 1948 (registration performed by the American Association of Nurserymen, AAN registration number 516, but no publication of registration action has been located by the present registrars). Registrant: W. B. Clarke, W. B. Clarke Nursery, San Jose, CA. This cultivar was selected by the registrant in Mar. 1946 as a seedling of Viburnum $\times$ burkwoodii 'Burkwood' from a large number 
of open-pollinated seedlings showing a range of variation between the parent and Viburnum carlesii. Viburnum $\times$ burkwoodii 'Carlotta' differs from the parent in its far stronger growth, its earlier coloring, red autumnal foliage, and more intense floral fragrance. Material sufficient for the designation of a nomenclatural standard for this cultivar is currently lacking.

Viburnum ×burkwoodii 'Sarcoxie'. Registered 28 Dec. 1978 (registration action previously unpublished). Registrant: Dale E. Wild (for Arthur O. Wild), Sarcoxie Nurseries, Sarcoxie, MO. Viburnum $\times$ burkwoodii 'Sarcoxie' originated from seeds obtained by controlled pollination of $V$. carlesii by $V$. $\times$ burkwoodii (itself a hybrid of $V$. carlesii and $V$. utile). The seedling was selected by Arthur O. Wild in 1971, and the cultivar was named and introduced by Dale Wild of Sarcoxie Nurseries in 1976. Viburnum $\times$ burkwoodii 'Sarcoxie' is generally more compact than either parent. Its foliage is glossy and more persistent than its Viburnum $\times$ burkwoodii parent, its flowers are similar in size and fragrance to $V$. carlesii, and fruit production is scant, similar to its $V$. carlesii parent. It is known to be hardy in USDA Zone 5. A recorded synonym for this cultivar is Viburnum $\times$ burkwoodii 'Bur-Carl'. This cultivar and its registration by Dr. Donald R. Egolf (U.S. National Arboretum, then ICRA for Viburnum) were recorded in an unpublished checklist compiled by the registrar's assistant, Anne O. Andrick, which was last updated in 1993. Material sufficient for the designation of a nomenclatural standard for this cultivar is currently lacking.

Viburnum carlesii 'Arlene'. Registered 17 May 1990 (registration action previously unpublished). Registrant: Arlene Monroe, Kingwood Nurseries, Inc., Mentor, $\mathrm{OH}$. Viburnum carlesii 'Arlene' originated as a chance seedling of Viburnum carlesii that was selected in June 1985 by Eric Lundberg at Kingwood Nurseries. It was subsequently named by Arlene Monroe and introduced for sale in Spring 1990. The cultivar is more compact in growth than the species, with leaves much glossier than those of $V$. carlesii 'Compacta'. Its flower buds are pink, open to creamy white flowers similar in size to the species, are 0.625 to 0.75 inches across, and have a strong fragrance. Inflorescences are 2.25 to 2.75 inches in diameter. Fruits are similar to the species but are more abundantly produced. Fall foliage colors are yellow, orange, and red. This cultivar and its registration by Dr. Donald R. Egolf (U.S. National Arboretum, then ICRA for Viburnum) were recorded in an unpublished checklist compiled by the registrar's assistant, Anne O. Andrick, which was last updated in 1993. Material sufficient for the designation of a nomenclatural standard for this cultivar is currently lacking.

Viburnum grandiflorum 'Snow White'. Registered 20 Sept. 1967 (registration action previously unpublished). Registrant: Eric Savill, Director of Gardens, Crown Estate Office, Windsor Great Park, Berkshire, England. Viburnum grandiflorum 'Snow White' originated at, and was introduced by, Crown Estate Commissioners,
Windsor Great Park, as a seedling of wild origin. Its habit is vigorous and its form is fastigiate, up to $8 \mathrm{ft}$ in height. Its leaves are oval, tapered toward both ends, finely toothed, dark green, 6 inches long, 2.75 inches wide, very firm in texture, and resistant to disease; its flowers are white. This cultivar and its registration by Dr. Donald R. Egolf (U.S. National Arboretum, then ICRA for Viburnum) were recorded in an unpublished checklist compiled by the registrar's assistant, Anne O. Andrick, which was last updated in 1993. Material sufficient for the designation of a nomenclatural standard for this cultivar is currently lacking.

Viburnum hanceanum 'Dwarf Fairy'. Registered 15 Feb. 2018. Registrant: WenJun Lü, Wuhan Botanical Garden, Wuhan City, Hubei Province, People's Republic of China. This cultivar, the first reported for Viburnum hanceanum, originated as a sport of a plant raised from material collected from the wild in Baiyunshan Nature Reserve, Baojing County, Xiangxi Tujia and Miao Autonomous Prefecture, Hunan Province. The sport occurred at Wuhan Botanical Garden. The plant was raised in 2011 and selected in 2014, when it was also first propagated by cuttings. It first flowered after propagation in 2017.

Viburnum hanceanum 'Dwarf Fairy' forms a small, compact, multi-stemmed shrub. Its leaves are oblong-obovate or elliptic, 2 to $2.5 \mathrm{~cm}$ wide, and 5 to $6.5 \mathrm{~cm}$ long. Inflorescences are compound umbel-like cymes, with large, sterile marginal flowers. Sterile flowers are white, irregularly four- or five-lobed, and reminiscent of the shape of a sulfur butterfly. Fertile flowers are small, yellow, and rotate, and they are not fragrant. The main flowering season is mid-April to May, similar to the species. After this period, it continues to flower repeatedly from August until February, but the flowers during this period are smaller than the first bloom. Fruit is sparse and not ornamentally effective. All of its leaves senesce in late December.

This cultivar may be differentiated from the species by its smaller leaves and low, creeping, and more compact habit. Fruit of $V$. hanceanum is typically abundant and showy, but the fruit of the new cultivar is sparse and not ornamentally effective. The new cultivar can repeat flower many times during the growing season and sheds its leaves completely in winter, whereas typical $V$. hanceanum only flowers once per year and is semi-evergreen, with $20 \%$ of its leaves remaining on the branches during winter.

Viburnum hanceanum 'Dwarf Fairy' grows best in acidic, moist, well-drained soil in full sun to partial shade. Its optimal temperature range for growth is 15 to $30^{\circ} \mathrm{C}$, with maximum and minimum recommended temperatures of $40^{\circ} \mathrm{C}$ and $-10^{\circ} \mathrm{C}$, respectively. Propagation is performed by cuttings, which may be rooted throughout the year but are particularly easy to root in May-June or August-September. Vermiculite is recommended as the optimal propagation medium, with rates of $100 \%$ rooting possible. Roots develop 15 to $20 \mathrm{~d}$ after sticking. Branches with terminal buds root better than those without.

Digital images have been submitted to the registrar. A nomenclatural standard specimen will be prepared and deposited at the Herbarium of the U.S. National Arboretum.

Viburnum plicatum var. tomentosum 'Cascade'. Registered 23 Jan. 1975 (registration action previously unpublished). Registrant: Jac. Schoemaker, Jac. Schoemaker B.V., Boskoop, The Netherlands. Viburnum plicatum var. tomentosum 'Cascade' originated as a seedling of 'Rowallane' that was selected by Schoemaker in May 1971, named, and introduced in the same year. The cultivar has widespreading branches that are slightly higher than those of 'Mariesii'. Its leaves are broadly ovoid, 7 to $10 \mathrm{~cm}$ long and 4 to $6 \mathrm{~cm}$ wide, with reddish petioles 1.5 to $2 \mathrm{~cm}$ long. Flowers appear in flat inflorescences $(8-10 \mathrm{~cm}$ in diameter) with six to eight bright white sterile florets that are 3 to $3.5 \mathrm{~cm}$ in diameter and small, creamy white fertile florets. Inflorescences are displayed horizontally on the branches. Flowering time is from the end of May to the beginning of June. Fruits are bright red and very prolific. The cultivar name was first published by H. J. van de Laar in Dendroflora (1971;8:69). This cultivar and its registration by Dr. Donald R. Egolf (U.S. National Arboretum, then ICRA for Viburnum) were recorded in an unpublished checklist compiled by the registrar's assistant, Anne O. Andrick, which was last updated in 1993. Material sufficient for the designation of a nomenclatural standard for this cultivar is currently lacking.

Viburnum plicatum var. tomentosum 'Glamour Girl'. Registered 24 Aug. 2018. Registrant: Wen-Jun Lü, Wuhan Botanical Garden, Wuhan City, Hubei Province, People's Republic of China. Viburnum plicatum var. tomentosum 'Glamour Girl' originated as a sport of a plant raised from material collected from the wild in Guanshan Nature Reserve, Yifeng County, Yichun City, Jiangxi Province. The sport occurred at Wuhan Botanical Garden. The plant was raised in 2011 and selected in 2014, when it was also first propagated by cuttings. It first flowered after propagation in 2017.

Viburnum plicatum var. tomentosum 'Glamour Girl' is a compact shrub, upright in habit, with a height of 0.7 to $1.3 \mathrm{~m}$ and spread of 0.8 to $1.0 \mathrm{~m}$ at 4 years of age. Leaves are ovate, oblong-obovate, or oblong-elliptic, 2.5 to $6.0 \mathrm{~cm}$ wide, and 3.9 to $9.7 \mathrm{~cm}$ long; they display a burgundy fall color. Inflorescences are borne along the length of the branches and are spectacular. The inflorescence is a compound umbel-like cyme and 4 to $4.6 \mathrm{~cm}$, with large sterile marginal flowers. The sterile flowers open pink and gradually fade to pale pink or pinkish white; they are irregularly four- or five-lobed. Fertile flowers are small, yellow, and rotate. The flowering season is mid-April to May, similar to typical $V$. plicatum var. tomentosum. The red fruits first turn red and then black when they reach full maturity in June. All leaves turn a strong burgundy fall color; then, they drop in late December. 
The new cultivar is similar to Viburnum plicatum var. tomentosum 'Pink Beauty', which also has pink flowers; however, flowers of 'Pink Beauty' open white and gradually fade to a strong, deep pink. The flowers of the new cultivar display the opposite color sequence, opening pink and fading to pale pink or pink-white. The flowering time of the new cultivar is also later than that of 'Pink Beauty'. The new cultivar has a burgundy fall color, but 'Pink Beauty' has not displayed fall color.

Viburnum plicatum var. tomentosum 'Glamour Girl' grows best in acidic, moist, well-drained soil in full sun to partial shade. Its optimal temperature range for growth is 15 to $30^{\circ} \mathrm{C}$, with maximum and minimum recommended temperatures of $40^{\circ} \mathrm{C}$ and $-10^{\circ} \mathrm{C}$, respectively. Propagation is performed by cuttings or tissue culture; cuttings may be rooted throughout the year but are particularly easy to root in August-September. Vermiculite is recommended as the optimal propagation medium, with rates of $100 \%$ rooting possible. Roots develop 15 to $20 \mathrm{~d}$ after sticking.

Digital images have been submitted to the registrar. A nomenclatural standard specimen will be prepared and deposited at the Herbarium of the U.S. National Arboretum.

Viburnum xrhytidophylloides 'Interduke' (generally sold with the trade designation DART'S DUKE). Registered 1 Dec. 1978 (registration action previously unpublished). Registrant: H. J. van de Laar, Research Station for Arboriculture, Boskoop, The Netherlands. Viburnum $\times$ rhytidophylloides 'Interduke' was originated by L. K. J. Ilsink, Darthuizer Nurseries, Leersum, The Netherlands. This cultivar arose as a hybrid of $V$. lantana and $V$. rhytidophyllum and was selected at Darthuizer Nurseries in $\approx 1965$. It was named and introduced by L. K. J. Ilsink of Darthuizer Nurseries in 1971. Its growth habit is very vigorous (to $2.5 \mathrm{~m}$ or more). Its leaves are broad-elliptic, 14 to $20 \mathrm{~cm}$ long, dark green, and semi-deciduous. Its flower clusters are very large, with cymes 14 to $18 \mathrm{~cm}$ in diameter, and flat to more or less rounded. Flowering occurs in October (November) and in spring. This cultivar and its registration by Dr. Donald R. Egolf (U.S. National Arboretum, then ICRA for Viburnum) were recorded in an unpublished checklist compiled by the registrar's assistant, Anne O. Andrick, which was last updated in 1993. Material sufficient for the designation of a nomenclatural standard for this cultivar is currently lacking.

Viburnum tinus 'Eve Price'. Registered 2 Dec. 1974 (registration action previously unpublished). Registrant: Assistant Curator, Royal Botanic Gardens, Kew, Wakehurst Place, Ardingly, Sussex, England. Viburnum tinus 'Eve Price' was purchased by the late Lord Wakehurst from Dicksons Ltd., Chester, England, in $\approx 1905$. It was named and exhibited before the Royal Horticultural Society 28 Feb. 1961 by Sir Henry Price, First Baronet, Wakehurst Place, Ardingly, Sussex, England, at which time it received an Award of Merit. Descriptions of this cultivar have been published [Gard. Chron. 1961;149(12):241 and Jour. Roy. Hort. Soc. 1961;86(7):326]. This cultivar and its registration by Dr. Donald R. Egolf (U.S. National Arboretum, then ICRA for Viburnum) were previously recorded in an unpublished checklist compiled by the registrar's assistant, Anne O. Andrick, which was last updated in 1993. Material sufficient for the designation of a nomenclatural standard for this cultivar is currently lacking.

Viburnum tinus 'Port of Nice'. Registered 30 May 1974 (registration action previously unpublished). Registrant: Neil G. Treseder, Treseders' Nurseries, Truro, Cornwall, England. This cultivar is believed to have originated as a chance seedling of $V$. tinus. The original plant was located beside the War Memorial overlooking the Port of Nice. The plant was selected by Neil Treseder in 1962, and it was named and introduced by Treseders' Nurseries in 1969. Its flowers are blush pink and cupped as in var. lucidum; its leaves are broader than those of typical Viburnum tinus subsp. tinus $(9 \mathrm{~cm} \times$ $4.5 \mathrm{~cm})$ and are glossy. The immature fruits are reddish brown, later turning black. The plant's habit is vigorous and open. This cultivar and its registration by Dr. Donald R. Egolf (U.S. National Arboretum, then ICRA for Viburnum) were previously recorded in an unpublished checklist compiled by the registrar's assistant, Anne O. Andrick, which was last updated in 1993. Material sufficient for the designation of a nomenclatural standard for this cultivar is currently lacking.

Viburnum tinus 'Spring Beauty'. Registered 30 May 1974 (registration action previously unpublished). Registrant: Neil G. Treseder, Treseders' Nurseries, Truro, Cornwall, England. This cultivar is believed to have originated as a seedling of $V$. tinus. The original plant was located in a private garden at Penryn, Cornwall, and was discovered by Neil G. Treseder in 1967. It was named and introduced by Treseders' Nurseries in 1969. Viburnum tinus 'Spring Beauty' develops into a compact bush. Its leaves are small, pointed, and $6 \mathrm{~cm} \times 2.5 \mathrm{~cm}$. Its flowers are pure white, and its fruits are blue-black. This cultivar and its registration by Dr. Donald R. Egolf (U.S. National Arboretum, then ICRA for Viburnum) were previously recorded in an unpublished checklist compiled by the registrar's assistant, Anne O. Andrick, which was last updated in 1993. Material sufficient for the designation of a nomenclatural standard for this cultivar is currently lacking.

Viburnum tinus 'Spring Bouquet'. Registered 28 Aug. 1974 (registration action previously unpublished). Registrant: James W. Hines, Jr., Hines Wholesale Nursery, Santa Ana, CA. Originated by the registrant and introduced by Hines Wholesale Nursery. This cultivar originated as a chance seedling of $V$. tinus. It was selected by James W. Hines, Jr., at San Gabriel, CA, in 1957, and it was named in 1965. Viburnum tinus 'Spring Bouquet' exhibits a dwarf, slow habit of growth, and it can be easily maintained at 3 to $4 \mathrm{ft}$ in height with little care. Its flower buds are red and open to white flowers almost covering the plant in early spring; its fruits are steel blue. This cultivar is known to be cold-hardy in USDA Hardiness Zone 7. The cultivar epithet was first published in the 1965 Hines Wholesale Nursery catalog; before that, it was sold as " $V$. tinus dwarf." This cultivar and its registration by Dr. Donald R. Egolf (U.S. National Arboretum, then ICRA for Viburnum) were previously recorded in an unpublished checklist compiled by the registrar's assistant, Anne O. Andrick, which was last updated in 1993. Material sufficient for the designation of a nomenclatural standard for this cultivar is currently lacking. 